Jolanta Żelazna

Uniwersytet Mikołaja Kopernika, Toruń

e-mail: jot_zna@umk.pl

\title{
Spinoza według Karla Jaspersa
}

DOI: http://dx.doi.org/10.12775/RF.2017.033

Pośród monumentalnych prac filozoficznych Karla Jaspersa, takich jak Filozofia, Von der Wahrheit, Wiara filozoficzna wobec Objawienia, szczególne miejsce zajmuje jego autorski namysł nad dziejami filozofii. Pod wspólnym tytułem Die großen Philosophen ${ }^{1}$ Jaspers zamierzał nakreślić losy myśli i znaczenie dziejowe wybranych filozofów i przewodników duchowych ludzkości. Przedstawiał ich metaforycznie jako mieszkańców wiecznego królestwa Wielkich², utworzonego z trzech głównych, powstałych samoistnie grup ${ }^{3}$, które ukazują się same, bez konieczności narzucania na dzieje filozofii jakichś kryteriów porządkowania. Pierwszy ukończony tom tego dzieła zawiera omówienie wielkości Ludzi wyznaczajacych miarę (tu należą Sokrates, Budda, Konfucjusz i Jezus), Płodnych założycieli filozofowania ${ }^{5}$ (Platon, Augustyn i Kant) oraz Metafizyków myślacych ze źródła ${ }^{6}$ (Anaksymander, Heraklit i Parmenides, Plotyn, Anselm, Spinoza, Lao-tse, Nagarjuna). W kolejnym, drugim, tomie Jaspers

1 Na podst.: Karl Jaspers, Die großen Philosophen, I, Piper Verlag, München 1959 (dalej cytuję jako: K. Jaspers, Die großen Philosophen. Wszystkie przekłady fragmentów - J. Ż.).

2 Ibidem, s. 10.

3 „Królestwo to ma ukrytą przed nami strukturę. Jeśli spodziewamy się znaleźć uporządkowania w grupach filozofów, to szukamy jej w jakimś odbiciu. Nie wytwarzamy jej, struktura ta sama się nam przedstawia. Wzdragamy się przed liczeniem wielkich. Ich liczba jest nieokreślona. Liczenie zdaje się stawiać ich w szeregu, co jest wobec nich niestosowne, skoro każdy jest jedyny i niezastępowalny i skoro nie istnieje jeden jedyny poziom, do którego należą". Ibidem, s. 45.

4 Die maßgebenden Menschen, ibidem, s. 105-228.

5 Die fortzeugenden Gründer des Philosophierens, ibidem, s. 229-616.

6 Aus dem Ursprung denkende Metaphysiker, ibidem, s. 617-956. 
zamierzał zgrupować Metafizyków szkicujacych ${ }^{7}$ (to Ksenofanes, Empedokles, Demokryt, Poseidonios, Bruno, Orygenes, Böhme, Schelling, Hobbes, Leibniz, Fichte), Rozluźniających ${ }^{8}$ (Abelard, Descartes, Hume, Pascal, Lessing, Kierkegaard, Nietzsche) i omówienie Budowli twórczych systematyków $w^{9}$ (Arystoteles, Tomasz, Hegel) ${ }^{10}$. Takie zestawienie i przyjęty klucz wyboru wiele mówią o Jaspersie - o osobie, filozofie i o nauczycielu. Wśród postaci opisanych w opublikowanym przez niego pierwszym tomie dzieła brakuje zaskakująco wielu tzw. podręcznikowych myślicieli, pojawiają się natomiast osoby nieuznawane powszechnie za filozofów.

Ukończone przez Jaspersa prace stanowią niezwykle obszerne dzieło, które - przekładane na różne języki - jeszcze za życia autora, przypuszczalnie ze względów komercyjnych, zostało podzielone na moduły mogące łatwiej niż całość znaleźć odbiorców zainteresowanych poszczególnymi zagadnieniami. Taki los spotkał anglojęzyczny przekład The Great Philosophers, z którego wydzielano różne fragmenty dotyczące m.in. Sokratesa, Buddy, Konfucjusza i Jezusa, presokratyków, czy św. Anzelma i Kuzańczyka. W każdym z takich excerptów wydawcy ograniczyli się do tekstu Jaspersa o wybranym myślicielu, całkowicie pomijając jego wprowadzenie objaśniające czytelnikom sposób przedstawiania biografii filozofa, jego poglądów, dokonań i inspiracji dla następców. Oddzielną książką stał się także tomik o Spinozie, filozofie tak „osobnym ${ }^{11 ", ~ z ̇ e ~ t r u d n o ~ d o ł a ̨ c z y c ́ ~ g o ~ d o ~ k t o ́ r e j k o l w i e k ~ p o s t a c i ~ o m a w i a-~}$ nej w dziele Jaspersa. W efekcie tego zabiegu, sięgając po tom, którego obwoluta zapowiada na przykład: Karl Jaspers, "from The Great Philosophers, Volume II, Anselm and Nicholas of Cusa", można sądzić, że mamy w ręku jeden $\mathrm{z}$ wielu akademickich podręczników historii filozofii. Jako taki okazuje się pracą nieudana, przedstawia postaci i poglądy w fałszywym świetle, budząc - zwłaszcza w przypadku Jaspersowskiego ujęcia

7 Die entwerfenden Metaphysiker, zob. ibidem, s. 48.

8 Die Auflockernden, zob. ibidem.

9 Die Gebäude der schöpferischen Ordner, zob. ibidem.

10 Kompletny zarys treści zamierzonego dzieła Jaspers umieścił we Wprowadzeniu, zob. ibidem, s. 46-49.

11 To szczególne miejsce Spinozy w dziele Jaspersa stało się faktem po wyłączeniu dotyczącego go rozdziału z kolejnego wydania angielskiego przekładu Die Großen Philosophen, nad którym czuwała H. Arendt. Por. K. Jaspers, The Great Philosophers, Vol. II, Anaximander, Heraclitus, Parmenides, Plotinus, Anselm, Nicholas of Cusa, Spinoza, Lao-tzu, Nagarjuna, New York: Harcourt, Brace \& World 1966, transl. R. Manheim, ed. H. Arendt oraz następne: K. Jaspers, „from The Great Philosophers, Volume II Anaximander, Heraclitus, Parmenides, Plotinus, Lao-tzu, Nagarjuna", New York: Harcourt Brace Jovanovich, transl. R. Manheim, ed. H. Arendt; K. Jaspers, „from The Great Philosophers, Volume II Anselm and Nicholas of Cusa", New York: Harcourt Brace Jovanovich, ed. H. Arendt, trans. R. Manheim, bez daty wyd.; K. Jaspers, "from The Great Philosophers, Volume II, Spinoza", New York and London, ed. by H. Arendt, transl. by R. Manheim, A Harvest/HBJ Book. 
postaci i nauczania Jezusa - fale krytyk i nierzadko oburzenia. Wielu z nich można by uniknąć, inne złagodzić, gdyby wydawcy poprzedzali zasadniczy tekst każdego tomu stosownym wprowadzeniem.

W Die großen Philosophen pośród nielicznych źródłowo myślących metafizyków Jaspers umieścił „mojego filozofa”"12 lat młodzieńczych, jak napisał o Spinozie w Autobiografii. Czy to nie paradoks, że filozof egzystencji, kantysta uznający apel za najwłaściwszy, bo nienaruszający ludzkiej wolności sposób filozoficznej komunikacji, pośród swoich wielkich czerpiacych ze źródła filozofii wymienił outsidera wykładającego more geometrico naukę o konieczności wszelkich zdarzeń?

Odpowiedź na to pytanie zawiera się w Przedstowiu Jaspersa do Die Großen Philosophen, gdzie czytamy, że od niemal pięćdziesięciu lat filozofię trapią dwa zachodzące równocześnie procesy: stopniowy upadek, polegający na zatraceniu jej własnej istoty w naukowości oraz próba oswobodzenia się z akademickich, naukowych ograniczeń, przejawiająca się w anarchii myślenia pozorującej wolność. Stąd pomysł, aby przywrócić doświadczenie spotkania z filozofią w jej własnym obszarze, to znaczy w królestwie czy też w rzeszy (Reich) wielkich myślicieli. Wymaga on, ,"aby uczynić obcowanie z wielkimi filozofami tak przystępnym, jak to tylko możliwe, ale także, aby nie łudzić pozorną prostotą tego, co głębokie. Czytelnik powinien sam mieć do czynienia z filozofią"13.

Obszerne Wprowadzenie do pierwszego tomu dzieła zawiera szereg objaśnień dotyczących idei ludzkiej wielkości ${ }^{14}$, odróżnienia filozofów od innych wielkich postaci, ustalenia kryteriów wielkości wśród filozofów, a na tej podstawie - nakreślenia obrazu „wiecznego królestwa wielkich filozofów"15. W czasach wspomnianego podwójnego kryzysu trapiącego filozofię Jaspersowską przepustką do tego królestwa są wskazówki dla czytelników, dotyczące stowarzyszania się z jego mieszkańcami. Przede wszystkim powinni oni jasno zdawać sobie sprawę z różnicy między rozpatrywaniem (betrachten) ich dzieł i obcowaniem (der Umgang) z nimi, bo tylko ten drugi sposób pozwoli nawiązać własną relację z osobami autorów, żyjących i zmarłych, epokowych i ponadczasowych.

12 K. Jaspers, Autobiografia filozoficzna, wyd. Comer, Toruń 1993, s. 10.

13 K. Jaspers, Die Großen Philosophen, s. 14.

14 Aby uniknąć nieporozumień, należy według Jaspersa odróżnić wielkość od sławy, sprawności, skuteczności i osobliwości, czyli kryteriów używanych już w antyku do zestawiania biografii polityków, lekarzy, prawodawców itp. Jaspers podkreśla, że w Niemczech dopiero w klasycyzmie i romantyzmie pojawiła się świadomość wielkości jako takiej. Upatrywano jej w dokonaniach świętych, bohaterów, poetów i myślicieli. Zob. K. Jaspers, Die Großen Philosophen, s. 35.

15 Ibidem, s. 15 (spis treści). 
Dzieła i ich autorzy zawsze pozostawali w obszarze działania ducha swojej epoki, toteż dostrzeganie ich wielkości ma kluczowe znaczenie dla rozumienia filozofii dziejów. O dynamice charakteryzującej dziejowy aspekt obcowania z filozofią Jaspers pisze wprost: „stanę się świadomy przestrzeni „mocy”, w której przez filozofowanie trwa walka duchów, niedająca się zakończyć w czasie, której pozór zakończeń udaje wiele wszystko jednoczących systemów, a owa moc je przełamuje i oto znów jest, w nowych postaciach. Ponieważ nie mogę uzyskać żadnego zewnętrznego stanowiska, sam widzę, jak walczę pośród ich wielości, i to nawet także przez moje ujmowanie mocy i frontów"16.

W dziejowej perspektywie łatwo narazić się na zarzut arbitralności wyboru Wielkich i zasad ich grupowania, a przy tym trudno obronić samą ideę wielkości czy uchronić się od „ubóstwienia człowieka”. Jaspers wskazuje na te i wiele innych zagrożeń i podkreśla, że „wszystko to nie powinno zniechęcać. Zadaniem pozostaje także i to, co nie jest możliwe do wykonania"17.

„Dzieje ma człowiek tam, gdzie wielkość mówi do niego z przeszłości"18. Widać ją w przekazie mitu i legendy o heroizmie walki, o porządkującej sile prawodawcy, objawieniu boskiej mocy, w ludzkich planach i wynalazkach, we wstrząsach i w wyzwoleniu przez poezję i sztukę, w rozjaśnieniu przez myśl. Jednak wielkość tych osiągnięć sama nie jest wymierna - uzyskać ją może tylko coś, co odnosi się do całości naszego istnienia, do świata, do transcendencji; swój sens wielkość otrzymuje od obejmującego ${ }^{19}$. Wielkość przysługuje tylko temu, co niezastępowalne, czego zaistnienie staje się możliwe poprzez jedność osoby i powszechnie ważnej dziejowo sprawy. Prawdziwość wielkości rozpoznajemy tam, gdzie rozszerzają się granice naszego bycia człowiekiem, gdy „w grozie i czci z pełną jasnością doświadczamy tego, co czyni nas lepszymi. Od wielkich ludzi pochodzi siła pozwalająca nam wzrastać przez naszą własną wolność; napełniają nas światem niewidzialnego, którego kształty przez nich zostają odkryte, którego język przez nich staje się słyszalny" 20 .

Tym, co według Jaspersa pozwala nam dostrzec wielkość, jest możliwość naszej własnej istoty i to ona daje nam dyspozycję do poważania (achten) każdego człowieka. To, kogo widzę wielkim, ujawnia mi, kim jestem. Nie dowiem się tego z psychologii, nie objaśni mi tego socjologia, do tej kwestii nie dotrę, posługując się najbardziej wyszukanymi metodami i testami. Nie trzeba się też obawiać, że pełen czci podziw wobec

16 Ibidem, s. 8.

7 Ibidem, s. 11.

8 Ibidem, s. 29.

9 Ibidem.

20 Ibidem, s. 31. 
wielkich mógłby nas doprowadzić do ubóstwienia człowieka (Menschenvergötterung) - człowiek zawsze pozostaje człowiekiem ${ }^{21}$, a wielkość w nim ujawnia się dopiero we wglądzie w całość jego rzeczywistości. Budzi ona w nas coś, co jest do niej podobne w każdym z nas - „kto widzi wielkość, doświadcza wezwania, by samemu się nią stać"22.

Filozofowie, święci, prorocy i poeci mają wspólne zadania i podobnie je wypełniają. Jest $w$ nich dążenie do „rozjaśniania tajemnic bytu i istnienia - ponadczasowa prawda w dziejowym kostiumie - wolność od partykularnych interesów w świecie ${ }^{23 "}$. Jednak o ile bohaterowie posługują się czynem, a prorocy i poeci obrazem, mitem i metafora, to filozofowie posługują się pojęciami i operacjami na pojęciach - tymi środkami osiągają coś, co stanowi o wielkości każdego z nich. To w nich myślenie dociera tam, gdzie myśli samo z siebie i gdzie zdaje się doświadczać, czym byłby byt $\mathrm{w}$ całości ${ }^{24}$.

Nie wszyscy myśliciele stają się wielkimi - ci, których Jaspers nazywa Die Großen Philosophen, spełniają szereg warunków: zewnętrznych, dotyczących materialnego istnienia ich dzieł (wyjątkami byli Sokrates i Budda) i ich inspirującego oddziaływania na następców oraz wewnętrznych, odnoszących się do treści pism lub zachowanych ustnych przekazów o ich nauczaniu. Warto przyjrzeć się dokładniej kryteriom wyliczonym przez Jaspersa $\mathrm{w}$ tym punkcie, ponieważ to one będą decydować o przynależności poszczególnych myślicieli do jednej z trzech wymienionych na początku grup mieszkańców wiecznego królestwa.

Po pierwsze, treści dzieł Wielkich "stoją w czasie ponad czasem” 25 należą niezaprzeczalnie do swojej epoki, mówią jej językiem, włączają do rozważań jej problemy i odkrycia, ale nadają im ponadczasowy sens. „Transcendencja w dziele i w życiu pozwala więc wielkiemu człowiekowi stać się zjawiskiem, które może przemówić do każdej epoki, do każdego" 26 .

Po drugie, tak jak każdy człowiek w ogóle, tak samo każdy rzeczywisty, autentyczny myśliciel jest źródłowy, gdy jest istotny i prawdziwy. Wielcy wśród nich są ponadto w swej źródłowości oryginalni, to znaczy wprowadzają nowe, nieistniejące wcześniej ujęcie problemu, czyniąc go przy tym łatwo zrozumiałym. Stworzenie takiego ujęcia okazuje się niepowtarzalne, ale też inspiruje następców i naprowadza ich na własne, oryginalne dokonania. Oryginalność jest jak „skok w dzieje” i nie polega na formułowaniu twierdzeń, lecz spoczywa w „duchu, z którego

21 Ibidem, s. 35.

22 Ibidem.

23 Ibidem.

24 Ibidem.

25 K. Jaspers, Die Großen Philosophen, s. 39.

26 Ibidem. 
pochodzi i który wiąże ją z wieloma innymi twierdzeniami" ${ }^{27}$. Warunek oryginalności Jaspers ilustruje ostatecznie przekładem cytatu o wielkich myślicielach zaczerpniętym z pism Emersona: „to, co wiedzą, wiedzą dla nas. Z każdym nowym duchem nowa tajemnica natury wychodzi na jaw i Biblia nie może zostać zamknięta, dopóki nie urodzi się ostatni wielki człowiek"28.

Po trzecie, prawdziwie wielki filozof uzyskał wewnętrzną niezależność, w której brak sztywności. Nie chodzi tu o upór, przekorę, doktrynę, której by fanatycznie bronił, lecz o uzyskanie absolutnego spokoju pośród nieustannych niepokojów dziejowych. Niezależność taka to pozostawanie otwartym, możność polegania na sobie i bycia dla siebie, zdolność wytrzymywania samotności bez szukania jej. "Niezależność mająca źródło w egzystencji stojącej w obliczu transcendencji umożliwia mu pozostawanie panem własnych myśli, panem swoich dobrych czynów i własnych zbłądzeń. Czyja jest ta niezależność, która wciąż wkracza w zależności? Tego, kto nie pojmuje siebie poza instancją którą nie tylko jest sam, lecz która warunkuje wszystko, rozumu; i pojęcie tego nigdy nie ma końca" ${ }^{29}$. Taka niezależność pozostawia ślady w myśleniu filozofa, jeśli jednak sam ją podkreśla jako swoją cechę, staje się wątpliwa: „wielkość ma siłę niezależności, ale ginie w dumnych roszczeniach do niezależności" ${ }^{30}$.

Kryterium wielkości według Jaspersa oprócz wymienionych cech tworzą również tzw. rzeczowe właściwości dzieła. Pierwszą i bodajże najważniejszą z nich jest kwestia odniesienia wiedzy filozoficznej, fundamentalnej, najogólniejszej, do szczegółowej wiedzy przedmiotowej. Relacja obu dziedzin $\mathrm{w}$ tym pasie granicznym stała się problematyczna już w czasach sofistów, ale dopiero w dwóch ostatnich stuleciach przyjęło się sądzić, że miarodajną cechą przynależności różnych dzieł do rzędu tzw. wielkich dokonań jest ich „naukowy” charakter ${ }^{31}$, co oznacza w filozofii systemowość i logiczną formę wywodu. „Ten standard sam stał się w efekcie wątpliwy. Dziś dochodzi się z jednej strony do ekstremum pozytywistycznej i logicyzującej naukowości, przy odrzuceniu wszelkiej metafizyki i tego, co znaczyła wcześniej filozofia. Z drugiej strony filozofia rozpuściła się we wrogim nauce sposobie używania afektowanego języka. Obydwie te sprzeczne możliwości wykluczają wielką filozofię. Ujęcie pierwsze pozwala się jej w ogóle zacząć dopiero w XIX w.,

27 Obydwa cytaty - ibidem.

28 „Was sie wissen, sie wissen's für uns. Mit jedem neuen Geist dringt ein neues Geheimnis der Natur ins Licht, und die Bibel kann nicht geschlossen werden, ehe nicht der letzte große Mensch geboren wurde" (Emerson); Ibidem.

29 Ibidem, s. 40, kursywa - J. Ż.

30 Ibidem.

31 Zob. ibidem - der Charakter der "Wissenschaft”. 
a wszelkie wcześniejsze jej przejawy uznaje za nieistotne. Drugie razem ze związkiem z nauką traci również powagę filozofii. Stosunek filozofii do nauk stał się dziś jednym z rozstrzygających problemów. Od zawsze jednak kryterium wielkiej filozofii jest sposób, w jaki nauka działa w jej obrębie" ${ }^{\prime 32}$.

Drugą rzeczową cechą wielkich dzieł filozoficznych jest ich służebny charakter wskazówki, pomagającej nam „uświadomić sobie nasze istnienie, istnienie świata, bytu, boskości. Pomijając inne poszczególne cele, filozofowie rozjaśniają naszą życiową drogę poprzez całość, są poruszeni problemem granic, poszukują czegoś, co ostatecznie zewnętrzne. Ich istotą jest uniwersalność. Oni sami urzeczywistniają ideę całości, jeśli nawet wyrażałoby się to tylko w kontemplacji i w symbolicznej dziejowości ich istnienia. To, co właściwe filozofom jako takim, uzyskuje wielkość przez treść tej całości"33. Jednak trzeba zauważyć, że w przypadkach, kiedy "całość nie działa na filozofa”, jego dzieła mogą wprawdzie mieć silny rezonans historyczny, lecz ich uniwersalność staje się schematyczna, treść - chociaż tu i teraz aktualna - pozostaje uboga, a sposób myślenia płaski ${ }^{34}$.

Ostatnią z wymienionych przez Jaspersa rzeczowych cech, charakteryzujących dzieła myśli filozoficznej, jest (najczęściej niezamierzony) rys „normatywności”, stający się w nich siłą poruszającą każdego, kto potrafi pytać równie dogłębnie, jak krytycznie. Działa ona z mocą autorytetu, którego pragnie się słuchać, a który, jeśli ku czemuś nakłania, to ku samodzielnemu poszukiwaniu, myśleniu, badaniu, tak abyśmy nie umniejszali własnej odpowiedzialności przez naśladowanie wzoru, lecz ją umacniali uzyskanym zrozumieniem. Od normatywności religijnej różni się ona tym, że filozof zawsze działa samodzielnie i w sposób w pełni wolny, podczas gdy normatywny charakter religii istnieje i trwa w relacjach społecznych (są to instytucje kościołów, urzędy, kontrola, cenzura, pouczenie i posłuszeństwo) ${ }^{35}$. Od normatywności naukowej z kolei różni ją to, że filozofia domaga się zawsze samego ludzkiego bycia w całości, podczas gdy nauce wystarcza sam rozum świadomości jako takiej ${ }^{36}$.

32 Ibidem.

33 Ibidem, s. 40-41.

34 Ibidem, s. 41.

35 Ibidem.

36 „,... der bloße Verstand des Bewußtseins überhaupt"; ibidem. 
Interesujący nas temat - Spinoza według Jaspersa - został ujęty w Die Großen Philosophen zgodnie z wyłożonymi wyżej zastrzeżeniami. Podstawą cytowania stała się edycja Philosophische Bibliothek, gdzie w niemieckim przekładzie wielu autorów ukazały się filozoficzne pisma i listy Spinozy, a jego biografię Jaspers nakreślił, posługując się opracowaniem C. Gebhardta, Spinoza: Lebensbeschreibungen und Gespräche ${ }^{37}$. Postać i dzieło Spinozy znalazły się w części zatytułowanej Myślacy źródłowo metafizycy, którą Jaspers rozpoczął od krótkiego naszkicowania sytuacji metafizyki w filozofii epoki post-kantowskiej. Nie może ona już trwać w swej pierwotnej postaci, ale też nie warto się łudzić, że myślenie metafizyczne stanie się reliktem minionych epok. To myślenie wiążące, zobowiązujące, a jego moc wypływa z jego źródła. Nie jest nim pęd do wiedzy i poznania, będący początkiem nauki. Efekty tego myślenia, bardziej zbliżone do wizyjności poezji niż do metodyczności nauk, wyrażają "prawdę powiązaną z podmiotowością myślącego"38 człowieka.

Współcześnie metafizyka nie stanowi już dla nas problemu. Transcendentalna filozofia "uporała się" niemalże skutecznie z powracającą w każdym pokoleniu potrzebą mierzenia się z pytaniami, skierowanymi $\mathrm{ku}$ regulatywnym ideom myślenia. $Z$ dawnych czasów pozostały jednak - i wciąż niepokoją - dzieła, w których spotykamy ludzi twórczych, gdy idzie o nadawanie kształtu czemuś, co zaledwie udało im się pomyśleć, pewnej wizji, obrazowi całości zbyt dynamicznemu i wielowymiarowemu, aby można go było wyłożyć linearnym językiem rzeczowego poznania. Dlatego wciąż wracamy do - jeśli można tak powiedzieć „wypartej" metafizyki, aby, jak sądził Jaspers, mogła ona „zostać zrozumiana w jej źródle i celu. Wówczas treść tej metafizyki odsłania się jako to, czym była ona od zawsze, nie jako przedmiot poznania, lecz jako świat myślenia, który jest wymowny dla możliwej egzystencji, ale jako sucha, wyuczalna treść, staje się niemy"39. Taka metafizyka wskazuje pokłady bezczasowej, podstawowej wiedzy, darzącej spokojem, nawet jeśli w pismach metafizyków wskazania te wyrażane są na wiele różnych, powierzchownie niezgodnych sposobów. W dziejach metafizy$\mathrm{ki}$ „owa podstawowa wiedza rozwija się jak temat muzyczny - z wielu motywów w nieskończone bogactwo - krąży w sobie, nabiera kształtów w zdumiewających obrazach myślowych. $Z$ nich przemawia zasadniczy nastrój wiedzy o bycie w poszczególnych zjawiskach dziejowych, które stają się ważne dla wszystkich zdolnych je rozumieć" 40 .

\footnotetext{
37 C. Gebhardt, Lebensbeschreibungen und Gespräche, Meiner-Verlag, Leipzig 1914.

38 K. Jaspers, Die Großen Philosophen, s. 619.

39 Ibidem, s. 621.

40 Ibidem, s. 622.
} 
Wśród wielkich metafizyków Zachodu było bodajże tylko dwóch czystych metafizyków, „,samodzielnych, wolnych od kościelnej formy religii: Plotyn i Spinoza" ${ }^{41}$. Im oraz metafizykom chrześcijańskim (Jaspers wymienia tu św. Anzelma, Eckharta i Kuzańczyka) „wspólne jest wiarygodne poczucie bezpieczeństwa życia w tym, co obmyślone spekulatywnie, co w ich teraźniejszość wnosi im rzeczywistość transcendencji. [...] Używają tej podstawowej wiedzy, którą wydobywaja, wprowadzając ją w świadomość własną i świata" ${ }^{42}$. Jej sens jest wieczny, nie dziejowy, dlatego unosi się ponad wszelkimi dziejami i kulturami, należy do skarbca królestwa Wielkich.

Posiłkując się ówczesną wiedza, Jaspers mocno osadził „swojego" Spinozę w realiach religijno-społeczno-politycznych Niderlandów XVII wieku. Na podstawie dostępnych mu biografii, uzupełnionych zapewne osobistymi doświadczeniami emigranta i własnymi obserwacjami klinicznymi, ocenił sytuację młodzieńca-Spinozy ${ }^{43}$ jako „niedobrowolną bezpodstawność" (die unwillige Bodenlosigkeit), w jaką popadł on we wczesnych latach dwudziestych swego życia i dostrzegł w niej silny impuls do poszukiwania „innej podstawy w wiecznej prawdzie, dostępnej człowiekowi jako człowiekowi. Jego myślenie stało się ucieczką odrzuconych, którzy powinni stanowić o sobie całkowicie sami. Stało się orientacją dla każdego człowieka, który szuka niezależności. Pewność, jaką ma sam rozum, znalazł w filozofii, a ona rozjaśniła i wypełniła jego życie" ${ }^{\prime 4}$.

Pisząc rozdział poświęcony Spinozie, Jaspers zauważył, że nie jest sprawą prostą poprawnie ująć potrzebę niezależności tego człowieka w świetle dostępnych materiałów. Nie jest to łatwe również i dziś, w sześćdziesiąt lat od ukazania się Die Großen Philosophen. Rzeczywiste dokonanie filozoficzne Spinozy możemy łatwo przekreślić, posługując się dostępną współcześnie teorią psychologiczną, w świetle której niemal cały okres jego dzieciństwa i młodości był przeżywaniem długotrwałych i powtarzających się traum, a decyzja o wyjeździe z Amsterdamu i poszukiwaniu takiego obszaru istnienia, w którym nic i nikt nie będzie mógł mu odebrać autonomii, to oczywista w jego sytuacji reaktancja. Jeśli nawet taka ocena miałaby bardzo dobrze ugruntowane podstawy, to zastrzeżenie Jaspersa utrzymuje się w mocy: należy się starać poprawnie ująć potrzebę niezależności Spinozy, ponieważ jego osobista

41 Ibidem, s. 622-623.

42 Ibidem, s. 624.

43 Jednym ze źródeł biograficznych wymienionych przez Jaspersa w rozdziale poświęconym Spinozie jest bardzo obszerne, kilkutomowe opracowanie Stanislava von Dunina-Borkowskiego. Pierwszy tom tego dzieła, Der Junge Spinoza. Leben und Werdegang im Lichte der Weltphilosophie (Münster 1910) w ścisły, a przy tym literacki sposób rekonstruuje psychologiczną sylwetkę przyszłego filozofa.

${ }^{44}$ K. Jaspers, Die Großen Philosophen, s. 755. 
sytuacja ma walor uniwersalny, natomiast unikatowy sposób rozwiązania kryzysu - przez wzrost, samo-transcendencję - ukazuje wzorcową drogę odzyskiwania zdrowia i dążenia do pełni człowieczeństwa.

Jak można osiągnąć taką postawę wobec siebie i świata? Wytłumaczenie jest zdaniem Jaspersa jedno: u podstaw „bycia Spinozą" znajdujemy uchwyconą za jednym zamachem (mit einem Schlage) „metafizyczną totalną wizję". Doprowadziła go do niej paląca potrzeba ułożenia życia pośród obcych mu w gruncie rzeczy ludzi ${ }^{45}$, a wypełnił ją „przez rozjaśnienie wrodzonej mu świadomości Boga, która, rozbudzona w dziecku przez tradycję biblijna, stała się jedyną i od niej wyłącznie zależało wszystko inne" ${ }^{\prime 46}$. Jego niezależność polegała zdaniem Jaspersa na „myśleniu prawdy i życiu prawda, to znaczy dla niego: byciem w Bogu. Taka niezależność w pewności swego Selbst ma charakter nieosobowy, ponieważ ów sposób stawania się sobą nie dba o własną osobę. U tego człowieka, który w całości jest obecny jako on sam, nie widać żadnego starania o siebie. Wydaje się, że nie ma tu żadnego rozmyślania o sobie, dumy i przemocy, że nigdy nie mają do niego przystępu" ${ }^{\prime 4}$.

Świadomość ta wyraża się równie dobrze w wyłożonej w Etyce koncepcji substancji i jej modi, jak w powtarzających się cytatach i odniesieniach do nauczania świętych: Jana i Pawła, które znajdujemy w różnych pismach Spinozy, a nawet w najpóźniejszych jego listach: „,w Nim mieszkamy, a On w nas" ${ }^{\prime 4}$, „w nim żyjemy i poruszamy się, i jesteśmy"49. Rację miał więc Jaspers, kiedy podkreślał, że to świadomość Boga, „wrodzona mu", a nie nabyta (w jaki sposób można by jej w ogóle nabyć?)

45 Po śmierci rodziców i relegowaniu go ze wspólnoty Izraela Spinoza został zmuszony do znalezienia sobie miejsca, zajęcia i środowiska, w którym mógłby żyć. Moment ostatecznego zerwania z otoczeniem jest z pewnością o czym dobitnie przekonał się K. Jaspers w 1948 r., kiedy zdecydował się na emigrację, "nowym początkiem życia", które w dobrych okolicznościach można ufundować na samodzielnie wybranych podstawach. Jeszcze zanim rozstał się z rodzina, Spinoza rozważał, jaki byłby dla niego najlepszy sposób życia, a efekty tych poszukiwań spisał w Traktacie o uzdrowieniu rozumu ludzkiego (zob. B. Spinoza, Traktat o uzdrowieniu rozumu ludzkiego, w: idem, Pisma wczesne, Warszawa 1969, pkt. 1-14, s. 341-347). Pisał tam m.in. o tym, że jego szczęście byłoby niemożliwe bez tego, by dzielić je z innymi podobnie myślącymi i odczuwającymi ludźmi.

46 K. Jaspers, Die Großen Philosophen, s. 759-760.

47 Ibidem, s. 756.

48 Tym cytatem z 1 Listu św. Jana $(4,13)$ rozpoczyna się Traktat teologiczno-polityczny Spinozy (zob. B. Spinoza, Traktat teologiczno-polityczny, Kęty 2000, s. 73).

${ }^{49}$ W liście do H. Oldenburga Spinoza napisał: „Powiadam, że wszystko jest w Bogu i wszystko się w Bogu porusza, a mówię tak razem z Pawłem ${ }^{1}$ i zapewne też razem z wszystkimi filozofami starożytnymi, jakkolwiek w inny sposób. Odważyłbym się nawet powiedzieć, że mówię to razem z wszystkimi starożytnymi Hebrajczykami, na ile można wnosić z niektórych przekazów, wielorako co prawda fałszowanych". Zob. Listy mężów uczonych do Benedykta de Spinozy oraz odpowiedzi autora wielce pomocne dla wyjaśnienia jego dzieł, Warszawa 1961, list 73, s. 316. ${ }^{1}$ Dz. 17,28. 
drogą pracy intelektualnej, pascalowskiego „nawyknienia” czy naśladowania autorytetu, jest tak samo jak spokój, spoczywanie, wytchnienie (die Ruhe ${ }^{50}$, tranquility w przekładzie na j. angielski ${ }^{51}$ ) - drogą i celem życia Spinozy. Czy takie życie można dzielić z innymi ${ }^{52}$, tzn. czy istnieje bodaj cień szansy spotkania istot ludzkich, których egzystencjalny kompas równie pewnie wskazywałby im ten, jeden jedyny punkt odniesienia? Doświadczenia, które zdobył w kontaktach z kolegiantami i innymi poszukiwaczami Boga, skłaniały Spinozę do wniosku, że afekt nadziei, nietrwałej radości powiązanej z ideą rzeczy przyszłej lub przeszłej, o której zdarzeniu się w pewien sposób wątpimy ${ }^{53}$, nie jest stanem umysłu zasługującym na podtrzymywanie.

A przecież „Spinoza nie był ani samotnym dziwakiem, ani aktywnym politykiem. Nie szukał żadnego innego zajęcia, jak tylko tego, by systematycznie rozwijać swoje pomysły i przenosić je na papier. [...] Jego spokojna godność wydaje się w równej mierze być wrodzoną istota, jak i efektem jego filozofii. Cały szereg anegdot pokazuje, że w istocie nie był zimny, jego temperament nie był zgaszony, a spokój nie był apatią. [...] Swoje listy Spinoza zamykał pieczęcią „,caute”. Faktycznie, uważnie dbał o swój spokój” ${ }^{54}$, czego nie można powiedzieć o ludziach w jego

50 Zob. cytat z listu Spinozy w: K. Jaspers, Die Großen Philosophen, s. 756.

51 K. Jaspers, From the Great Philosophers. Vol. II. Spinoza, trans. R Manheim, ed. H. Arendt, Harcourt Brace Jovanovich, New York and London, bez daty wyd., s. 6.

${ }^{52}$ W rozterkach młodego Spinozy Jaspers dostrzegał głęboką potrzebę egzystencjalnej komunikacji dokonującej się w wolności i we wspólnocie przeżywania momentu dziejowego, ale możliwej tylko jako odpowiedź na apel. Widać ją już we wczesnych jego pismach (zob. s. 44, przyp. 55 tego artykułu), powtarza się też w dwóch końcowych częściach Etyki, gdzie równy nacisk położony jest na konieczność doświadczania afektów i na możliwość uwolnienia się od skutków ich działania, i gdzie zarazem Spinoza pozostawia wybór czytelnikowi, nawet jeśli nie zechce on podjąć żadnego starania o własną pomyślność: „wszystko, co doskonałe (praeclara), jest równie trudne, jak rzadkie" (B. Spinoza, Etyka w porządku geometrycznym dowiedziona, Warszawa 1954, cz. V, tw. 42, przyp., s. 376). Wspomnianą tu wątpliwość można też rozumieć jako skierowane do Descartes'a pytanie o to, czy proklamowane przez niego powszechnie ludzkie, wrodzone, proste intuicje dotyczące istnienia i istoty Boga, realnie wystarczają jako pewna podstawa metody poszukiwania prawdy egzystencji? Descartes dowodził, że są one fundamentem wytrzymującym próby uzasadnienia prawdziwości wiedzy o istnieniu natury, rozciągającej się poza ograniczeniami rzeczy myślących. Czy odkrywanie prawdy egzystencji było równie głęboką potrzebą Descartes'a, jak Pascala czy Spinozy, czy też raczej należałoby sądzić, że fundamenty ludzkich egzystencji są źródłowo tak różne, iż niektóre z nich z zasady nie będą zdolne do komunikacji z sobą? Podobny trop wskazuje J. Kopania w swoim artykule O powodach irytacji Kartezjusza stanowiskiem Gassendiego, zob. „Idea. Studia nad strukturą i rozwojem pojęć filozoficznych" 2015, t. XXVII,, s. 13-40, zwłaszcza s. 25, 28.

${ }_{53}$ Zob. definicję afektu nadziei w: B. Spinoza, Etyka..., cz. 3, def. XII, s. 221.

54 K. Jaspers, Die Großen Philosophen, s. 756. Kolejność cytatów nie pokrywa się $\mathrm{z}$ tekstem Jaspersa. 
najbliższym ani w dalszym otoczeniu. Wydaje się, że przedkładali oni życie wypełnione namiętnościami, pełne niepokoju, obaw, uniesień i rozczarowań nad rozumny autodyktat, pozwalający nie tylko widzieć, co dobre, ale wybierać tylko dobro samo, bezwzględne, takie, że gdy się je znajdzie, karmi umysł czystą radością i jest wolne od wszelkiego przesytu. Takim dobrem jest według Spinozy „znajomość jedności, jaka duszę ludzką łączy z całą Naturą" i staranie o to, by w miarę możności „wielu innych przyswoiło ją sobie wraz ze mną. Innymi słowy, do szczęścia mojego należy również troska o to, by wielu innych ludzi rozumiało to samo, co ja oraz żeby rozum ich i pragnienia najzupełniej z moim rozumem tudzież moimi pragnieniami się zbiegały" 55 .

Można zgodzić się ze stwierdzeniem, że Jaspers nie stara się być odkrywczy w swoim ujęciu filozofii Spinozy i poprzestaje na poprawnym sposobie zarysowania jej treści. Jedynie w sposobie dobierania cytatów (nota bene, cytowania są luźne, często wprowadzane z pamięci, niefilologiczne, jak czytamy we Wrowadzeniu ${ }^{56}$ do dzieła) i komentarzy do nich widać, z jaką intencją umieścił postać i dzieło Spinozy w części zatytułowanej Aus dem Ursprung denkende Metaphysiker. W filozofii Jaspersa źródłem jest egzystencja, nieprzedmiotowość, którą jestem i która w szyfrach szuka możliwości przekraczania siebie ku możliwej egzystencji Innego, podejmuje próby komunikacji z nią w wolności.

Ludzka historyczność określa, jakiego rodzaju znakami szyfrujemy przesłanie wolności. W czasach Spinozy takim znakiem obejmującym całość istnienia stał się system. Treścią jego systemu jest jednak filozofia praktyczna, ukazująca sposób, w jaki można przekroczyć siebie, istnieć bardziej. Opisując drogę Spinozy, Jaspers często wskazuje na znaczenie doświadczania, uświadamiania sobie treści, wagi i doniosłości przeżyć mens humana, której nie sposób sprowadzić do samego tylko rozumu i do prób racjonalnego przełożenia pojęć (die Begriffe) na terminy łacińskiej filozofii. W Die Großen Philosophen widać, że Jaspersowski Spinoza apeluje do czytelnika ze źródłowego pokładu egzystencji: bierz, czytaj, zrozum i spróbuj, gdyż i ty jesteś czymś więcej, niż ci się wydaje, że jesteś.

\section{Bibliografia}

Jaspers K., Autobiografia filozoficzna, Wyd. Comer, Toruń 1993.

Jaspers K., Die Großen Philosophen, Bd. I, Piper \& Co. Verlag, München 1959.

55 Obydwa cytaty pochodzą z: B. Spinoza, Traktat o uzdrowieniu..., op. cit., pkt 14, s. 346-347.

56 Zob. K. Jaspers, Die Großen Philosophen, s. 101. 
Jaspers K., The Great Philosophers, Vol. II: Anaximander, Heraclitus, Parmenides, Plotinus, Anselm, Nicholas of Cusa, Spinoza, Lao-tzu, Nagarjuna, transl. R. Manheim, ed. H. Arendt, Harcourt, Brace \& World, New York 1966. Jaspers K., The Great Philosophers, Vol. II: Anaximander, Heraclitus, Parmenides, Plotinus, Lao-tzu, Nagarjuna", transl. R. Manheim, ed. H. Arendt, Harcourt Brace Jovanovich, New York, bez daty wyd.

Jaspers K., From the Great Philosophers. Vol. II, Anselm and Nicolas of Cusa, trans. R Manheim, ed. H. Arendt, Harcourt Brace Jovanovich, New York, bez daty wyd.

Jaspers K., From the Great Philosophers. Vol. II, Spinoza, trans. R Manheim, ed. H. Arendt, A Harvest/HBJ Book, New York and London, bez daty wyd.

Dunin-Borkowski S. von, Der Junge Spinoza. Leben und Werdegang im Lichte der Weltphilosophie, Münster 1910.

Gebhardt C., Lebensbeschreibungen und Gespräche, Meiner-Verlag, Leipzig 1914.

Kopania J., O powodach irytacji Kartezjusza stanowiskiem Gassendiego, „Idea. Studia nad strukturą i rozwojem pojęć filozoficznych" 2015, t. XXVII.

Listy męzó́w uczonych do Benedykta de Spinozy oraz odpowiedzi autora wielce pomocne dla wyjaśnienia jego dzieł, Warszawa 1961.

Spinoza B., Etyka w porzadku geometrycznym dowiedziona, Warszawa 1954.

Spinoza B., Traktat o uzdrowieniu rozumu ludzkiego, w: idem, Pisma wczesne, Warszawa 1969.

Spinoza B., Traktat teologiczno-polityczny, Kęty 2000.

\section{Streszczenie}

Die Großen Philosophen Karla Jaspersa to późna praca zawierająca autorski, osobisty wybór i uszeregowanie myślicieli, nie mające nic wspólnego z akademicko-podręcznikowym wykładem dziejów filozofii. Ideą przewodnią jest tu namysł nad ludzką wielkością, przejawiającą się w dziejach filozofii jako osobowy wzór człowieczeństwa, inspirujące sposoby filozofowania, źródłowa myśl metafizyczna i przykłady twórczej systematyki. Wśród metafizyków "źródłowych” Jaspers umieścił Spinozę, przedstawiając jego filozofię w kontekście egzystencjalnym. To niezwykłe odczytanie staje się czytelne dopiero po zestawieniu treści rozdziału "Spinoza” z uwagami, zawartymi we Wprowadzeniu do Die Großen Philosophen, które zwykle pomija się w różnych częściowych edycjach dzieła Jaspersa.

Słowa kluczowe: Jaspers, Spinoza, Die Großen Philosophen, idea wielkości 


\section{Summary}

\section{Karl Jaspers on Spinoza}

Die Großen Philosophen is a late work by Karl Jaspers based on his individual selection and order of thinkers, quite different from the one offered in an academic lecture on the history of philosophy. The main idea of the work is to consider human greatness which finds its expression in the history of philosophy in a form of a one's own personal experience and a model of humanity which inspires various ways of philosophising, a source metaphysical thought, and an example of creative systematics. Jaspers places Spinoza among "source" metaphysicians and presents his philosophy in the existential context. This unusual interpretation becomes comprehensible only when the content of the chapter on Spinoza is read in contrast to the context of remarks included in the introduction to Die Großen Philosophen which is usually omitted in partial editions of the work by Jaspers.

Keywords: Jaspers, Spinoza, The Great Philosophers, the idea of the greatness 